\title{
OPEM
}

www.opem.org

Oriental Pharmacy and Experimental Medicine 2008 8(4), 386-394

DOI 10.3742/OPEM.2008.8.4.386

\section{Pharmacological and Biochemical studies on Telescopium telescopium - a marine mollusk from the Mangrove regions}

\author{
SK Samanta ${ }^{1}$, D Adhikari ${ }^{1}$, S Karmakar ${ }^{1}$, A Dutta ${ }^{1}$, A Roy ${ }^{1}$, KT Manisenthil ${ }^{1}$, D Roy $^{1}$, JR Vedasiromoni ${ }^{2}$ \\ and T Sen ${ }^{1, *}$ \\ ${ }^{1}$ Division of Pharmacology, Department of Pharmaceutical Technology, Jadavpur University, Kolkata 700032, \\ India; ${ }^{2}$ Drug Development Division, Indian Institute of Chemical Biology, 4 Raja S.C. Mullick Road, Kolkata, \\ 700032, India
}

Received for publication October 18, 2007; accepted April 03, 2008

\begin{abstract}
SUMMARY
The tissue extract (TTE) of a marine snail Telescopium telescopium, collected from the coastal regions of West Bengal, India, was extensively screened for pharmacological and biochemical properties. Telescopium telescopium (TTE) produced significant lysis of washed rat erythrocytes (both direct and indirect), produced haemorrhagic lesions in the skin and also released haemoglobin (in vitro tissue damage) from different tissue samples. TTE was found to produce pro-inflammatory effects when injected into the rat hind paw and also increased peritoneal vascular permeability. Furthermore, intravenous administration of TTE produced a decrease in blood pressure (hypotensive effect) in anaesthetized rats. The extract produced potent esterase activity, as was evident from the breakdown of FDA with subsequent release of fluorescein (in vitro). TTE also demonstrated prominent cholinesterase, phospholipase, phosphatase and protease activities.
\end{abstract}

Key words: Mollusk; Telescopium telescopium; Haemolysis; Oedema; Phospholipase; Cholinesterase

\section{INTRODUCTION}

Biologically active chemical compounds isolated from cone snails (belonging to the Phylum Mollusca) have found application in medicine and also in research. More than 2600 scientific studies have been carried out over the past 20 years on different species of this phylum. Apart from conotoxins ( $\alpha$, $\omega$ and $\mu$; Myers et al., 1993), kahalide $\mathrm{F}$, a depsipeptide present in the marine mollusk Elysia rufescens, has been reported to posses anti-cancer as well as anti-HIV activities (Hamann et al., 1996).

${ }^{*}$ Correspondence: T Sen, Division of Pharmacology, Department of Pharmaceutical Technology, Jadavpur University, Kolkata-700032, India. E-mail: tssen@hotmail.com
Telescopium telescopium, a marine multicellular organism, belonging to the phyllum Mollusca, is widely found in the Indian subcontinent, particularly in the eastern coastline and also in the Sunderban Mangroves. Survey of literature revealed the presence of potent anti-microbial (Pakrashi et al., 2000) and immunocontraceptive (Pakrashi et al., 1992) substances in the spermathecal gland of Telescopium telescopium. Moreover, two endo-(1 linked to3)-beta-D-glucanases (Cutler and Yellowlees, 1979) have also been purified from this mollusk.

However, till date there is an acute dearth of information related to the pharmacological and biochemical properties of Telescopium telescopium. Accordingly, in the present study, an attempt has 
been made to explore the pharmacological and biochemical properties of the tissue extract with particular reference to the enzymatic activities.

\section{MATERIAL AND METHODS}

\section{Collection and Identification}

Live molluskan species of Telescopium telescopium were collected from the creeks of the river Matla, in the Jharkhali area of Sundarbans, West Bengal (India). The Zoological Survey of India (ZSI) New Alipore, Kolkata, India, carried out the identification of the sample.

\section{Preparation of extract}

The outer hard shell was removed; the soft tissue portion was homogenized with three volumes of $20 \mathrm{mM}$ phosphate buffer ( $\mathrm{pH} 7.2 ; 5 \mathrm{~min}$ ), thereafter the sample was sonicated for $2 \mathrm{~min}$ and centrifuged (r.p.m. 10000). The pooled extract was defatted with dichloromethane (DCM) and concentrated under reduced pressure. The DCM cut extract (TTE) was subsequently freeze-dried and stored at $-20{ }^{\circ} \mathrm{C}$.

\section{Protein Estimation}

Protein concentration was estimated following the method of Bradford (1976), using standard Bradford Kit (Gene) and the concentrations of the extract (unless otherwise specified) was expressed in terms of protein equivalent.

\section{Animals Used}

The pharmacological experiments were conducted using adult Swiss albino mice (18 - $22 \mathrm{gm}$ ) and rats of Charles Foster strain (120 - $180 \mathrm{gm})$. The animals were used after an acclimatization period of at least 10 days in the laboratory environment and were housed in standard plastic cages with food and water ad libitum. Control vehicle or test materials were administered intraperitoneally unless otherwise specified. All the experiments were performed according to the guidelines of the Institutional
Animal Ethical Committee (constituted under the guidelines Committee for the Purpose of Control and Supervision of Experiments on Animals, India).

\section{Acute Toxicity Study - Determination of $\mathbf{L D}_{50}$}

For testing of lethality, predetermined doses of the extracts were administered (i.p.) to male mice (18 $22 \mathrm{gm}$ ) and the animals were observed (24 h) for signs and symptoms of toxicity and the mortality in each group $(n=20)$ was recorded. $\mathrm{LD}_{50}$ was determined according to the method of Litchfield and Wilcoxon (1949).

\section{Haemolytic activity}

Haemolytic activity of animal toxins can be categorized into two groups: i) those, which produce direct haemolysis of washed erythrocytes and ii) indirect action (requiring the presence of lysolecithin) for inducing haemolysis (Rosenfeld et al., 1962).

\section{Direct Haemolytic activity}

Direct haemolytic activity on washed rat erythrocytes was determined according to the method of Boman and Kaletta (1957), with some modifications. Washed erythrocyte suspension (final concentration of $1 \%$ ) was incubated (at $37^{\circ} \mathrm{C}$ for $45 \mathrm{~min}$ ) with different concentrations (in terms of protein equivalent) of TTE, with occasional shaking. Two control samples were included, one without TTE with saline and another with distilled water (for producing 100\% lysis of the RBC suspension). The reaction was terminated by rapid cooling, with ice-cold normal saline. The tubes were then centrifuged for $5 \mathrm{~min}$ and the absorbance was recorded at $540 \mathrm{~nm}$.

\section{Indirect Haemolytic activity}

Indirect haemolytic activity was assayed using a modification of the method described by RochaCampos et al. (1996). Erythrocyte suspensions [1\% (v/v); in $6 \mathrm{mM}$ calcium chloride] were incubated $\left(45 \mathrm{~min}, 37^{\circ} \mathrm{C}\right)$ with various concentrations of TTE $(5 \mu \mathrm{g} / \mathrm{ml}$ to $120 \mu \mathrm{g} / \mathrm{ml})$ and $30 \mu \mathrm{g} / \mathrm{ml}$ of lecithin. The reaction was stopped following 
addition of $1 \mathrm{ml}$ ice-cold PBS. However, in case of the control, $100 \%$ lysis was achieved with the addition of distilled water. Finally the samples were centrifuged at around $2000 \mathrm{rpm}$ (5 min) and the absorbance of the supernatant was measured at $540 \mathrm{~nm}$.

\section{Haemorrhagic and necrotizing activities}

The haemorrhagic activity of TTE was evaluated following the modified method of Gutierrez et al. (1985) TTE (5 $\mu \mathrm{g})$, was injected in mice (intradermally) and after $2 \mathrm{~h}$, the animals were sacrificed. The skin, of the mice were carefully removed and observed for the presence of haemorrhage. Different doses of TTE $(10,20,30,40$ and $50 \mu \mathrm{g} / \mathrm{rat})$ were injected into the dorsal shaved skin of six rats and after $72 \mathrm{~h}$ the animals were sacrificed by ether inhalation; their skins were removed and observed for the presence of necrosis (Theakson and Reid, 1983).

\section{Pathophysiological effect of TTE (in vitro tissue damage)}

Fresh chicken liver, heart and lungs were washed with normal saline and then the tissue samples (300 $\pm 10 \mathrm{mg}$ ) were incubated in $1 \mathrm{ml}$ of $0.2(\mathrm{M})$ K-phosphate buffer at $\mathrm{pH}-7.4$ for $45 \mathrm{~min}$ at $37^{\circ} \mathrm{C}$. The tissues were then washed and again incubated with TTE (50 $\mu \mathrm{g} / \mathrm{ml})$ in $3 \mathrm{ml}$ of 0.2 (M) K-phosphate buffer $\left(\right.$ at $\left.37^{\circ} \mathrm{C}\right)$. After incubation, reaction mixtures were centrifuged for $5 \mathrm{~min}$ at 3000 r.p.m. and the absorbance of the supernatant was read at $540 \mathrm{~nm}$. The percentage of haemoglobin released was calculated with respect to the tissue sample incubated with $0.1 \%$ Triton $\times 100$ solution (Datta and Bhattacharya, 1999).

\section{Effect of the TTE on peritoneal dye leakage}

Male albino mice (18 - 22 g) were divided into different groups, which received intraperitoneal injection of normal saline, TTE or aspirin. After $3 \mathrm{~h}$, the animals received $4 \mathrm{ml}$ of $0.05 \mathrm{~N}$ acetic acid in $0.9 \%$ saline (i.p.), followed by the administration of $0.1 \mathrm{ml}$ of $4 \%$ Pontamine Sky Blue (i.v.). After $1 \mathrm{~h}$, the animals were sacrificed by cervical dislocation; the abdomen was opened and peritoneal exudates collected. The exudates were centrifuged for 10 min at 2000 r.p.m. and the concentration of the dye was determined at $625 \mathrm{~nm}$ (Sen et al., 2007).

\section{Exudative inflammation}

Male albino mice, randomly divided into different groups, were treated with control vehicle (normal saline), TTE or aspirin (i.p.). After a period of $1 \mathrm{~h}$, $4 \mathrm{ml}$ of $0.05(\mathrm{~N})$ acetic acid (in $0.9 \%$ saline) was administered (i.p.) to the different groups. The animals were sacrificed after $3 \mathrm{~h}$, and the peritoneal exudates were collected (Sen et al., 2007). The amount of protein present in the exudates was measured by the method of Bradford (1976).

\section{Release of Autacoids}

The effect of TTE on histamine release was examined on mast cells prepared after Bloom and Hagemark, 1965. The prepared mast cells were incubated $\left(37^{\circ} \mathrm{C}\right.$; $\left.30 \mathrm{~min}\right)$ with either the buffer (control), TTE (50, 100, $250 \mu \mathrm{g} / \mathrm{ml}$ ) or compound $48 / 80(100 \mu \mathrm{g} / \mathrm{ml})$ as positive control. After incubation, the suspensions were centrifuged and the supernatant was used for further experimentation. For 100\% release of histamine, one set of cell suspension was boiled with $0.1(\mathrm{~N}) \mathrm{HCl}$ and neutralized with $\mathrm{NaOH}$.

Assay of histamine was performed on atroponized $\left(10^{-7} \mathrm{~g} / \mathrm{ml}\right)$ guinea pig ileum (in Tyrode solution, at $32-35^{\circ} \mathrm{C}$, with oxygenation). The concentration dependent responses (contact time of $30 \mathrm{~s}$ and 5 min time cycle) were then recorded. The presence of histaminic activity was confirmed by mepyramine $\left(10^{-8} \mathrm{~g} / \mathrm{ml}\right)$, used as specific antagonist (Hamann, 1943). 5HT release was also studied with suspended rabbit platelets (Toh, 1956) pre-incubated with reserpine (serotonin releaser; $3 \times 10^{-7} \mathrm{~g} / \mathrm{ml}$ ), TTE or normal saline, at $37^{\circ} \mathrm{C}$ for $4 \mathrm{~h}$. After incubation, the samples were acidified with $0.1 \mathrm{~N} \mathrm{HCl}$ and were subsequently assayed on isolated rat uterus (Toh, 1956). 


\section{Rat Blood Pressure}

Male Sprague-Dawley rats (250-300 g) were anesthetized with pentobarbitone sodium $(50 \mathrm{mg} /$ $\mathrm{kg}$, i.p.). The blood pressure was recorded via carotid artery, using Grass Polygraph (Model 79), while the jugular vein was used as drug port (Puri and Saha, 2003).

\section{Oedemogenic activity}

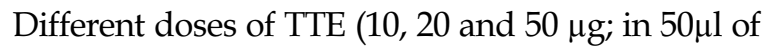
sterile saline) were administered into the subplantar region of the left hind paw. The contra lateral paw received the same volume of sterile saline. Edema was measured with a plethysmometer, at hourly intervals up to the $6^{\text {th }} \mathrm{h}$. Results were then calculated as the difference in paw volumes (Gutierrez et al., 1986).

Evaluation of Phospholipase $\mathbf{A}_{\mathbf{2}}\left(\mathbf{P L A}_{\mathbf{2}}\right)$ activity. $\mathrm{PLA}_{2}$ activity was evaluated using a modification of the method of Lobo et al. (1987). TTE in predetermined doses were added to $1.5 \mathrm{ml}$ of 100 $\mathrm{mM} \mathrm{NaCl}$ at pH 7.6 (containing $10 \mathrm{mM} \mathrm{CaCl}, 7$ $\mathrm{mM}$ Triton $\times 100,0.265 \%$ Lecithin, $98.8 \mu \mathrm{M}$ Phenol Red). The change in absorbance of the reaction mixture was measured at $558 \mathrm{~nm}$.

Effect of TTE on Fluorescein diacetate (FDA) hydrolysis (Esterase activity)

Measurement of hydrolysis of the Fluorescein diacetate (FDA) was performed following the modified method of Battin (1997). Reaction mixture containing TTE ( $5 \mu \mathrm{g} / \mathrm{ml}$ to $100 \mu \mathrm{g} / \mathrm{ml}$ ), Maclivian buffer ( $\mathrm{pH}$ 7.20) and $5 \mathrm{mM}$ FDA were incubated for $30 \mathrm{~min}$. at $40^{\circ} \mathrm{C}$. The reaction was terminated by the addition of $1 \mathrm{ml}$ ice-cold Maclivian buffer. The samples were centrifuged (10000 r.p.m; 5 min) and the absorbance of the supernatants were measured at $490 \mathrm{~nm}$.

The enzymatic activities of the samples were quantified as $\mu \mathrm{g}$ of fluorescein produced per $\mu \mathrm{g}$ of protein equivalent per min ( $\mu \mathrm{g}$ of fluorescein/ $\mu \mathrm{g}$ of test protein/min). The standard curve was prepared with different concentrations of Fluorescein di-sodium.

\section{Determination of Acetylcholine Esterase (AChE) activity}

The AChE activity was determined by colorimetric assay, according to the method of Ellman et al. (1961). The reaction mixture $(1 \mathrm{ml})$ containing 100 $\mathrm{mM}$ sodium phosphate buffer ( $\mathrm{pH} 7.0), 1 \mathrm{mM}$ acetylthiocholine iodide (ACTI; Sigma) and TTE were incubated at $25^{\circ} \mathrm{C}$ for $10 \mathrm{~min}$, followed by the addition of $1 \mathrm{mM} 5,5^{\prime}$-dithio bis-2-nitro benzoate (DTNB; Boehringer Mannheim). After $30 \mathrm{~min}$, the absorbance was measured at $412 \mathrm{~nm}$.

One unit of enzyme is defined as the amount of enzyme required to hydrolyze 1 micromole $(\mu \mathrm{m})$ of the substrate in $1 \mathrm{~min}$.

\section{Alkaline Phosphatase activity}

Reaction mixture containing TTE, $50 \mathrm{mM}$ diethanolamine ( $\mathrm{pH}$ 10.4), $50 \mathrm{mM} \mathrm{NaCl}, 2.5 \mathrm{mM}$ $\mathrm{MgCl}_{2}, 5.0 \mathrm{mM}$ p-nitrophenyl phosphate (p-NPP) was incubated at $37^{\circ} \mathrm{C}$ for $10 \mathrm{~min}$. Thereafter reaction was stopped by the addition of $2 \mathrm{ml}$ of $0.5 \mathrm{M} \mathrm{NaOH}$ and the amount of p-nitrophenol released was determined spectrophotometrically at $410 \mathrm{~nm}$.

One unit of enzyme was defined as the amount that liberated $1 \mu \mathrm{mol} / \mathrm{min}$ of p-nitro phenol (Binngham et al. 1992).

\section{Protease activity}

The proteolytic effect of TTE was evaluated following the method of Doley and Mukerjee (2003). Casein $1 \%(\mathrm{w} / \mathrm{v})$ in $20 \mathrm{mM}$ phosphate buffer containing $150 \mathrm{mM} \mathrm{NaCl},(\mathrm{pH}$ 8.0) was incubated with different concentrations of TTE for $1 \mathrm{~h}$ at $37^{\circ} \mathrm{C}$. Thereafter, $0.5 \mathrm{ml}$ of $10 \%$ TCA was added to the reaction mixture and the samples were centrifuged. The amount of digested protein $(\mu \mathrm{g} / \mathrm{ml})$ in the supernatant was determined using Folin-Ciocalteau's reagent.

One unit (U) of proteolytic enzyme activity (protease) was defined as that amount which liberates $1 \mu \mathrm{g}$ amino acids in $1 \mathrm{~min}$. 


\section{Statistical analysis}

Results were expressed as mean \pm S.E.M $(n=10)$. Statistical analyses were performed with one way analysis of variance (ANOVA) followed by Student's $t$ test or Post Dunnet's test, wherever applicable. $P<0.05$ was considered to be statistically significant.

\section{RESULTS}

\section{Acute Toxicity Study}

After $24 \mathrm{~h}$ of study, the $\mathrm{LD}_{50}$ of the extract (TTE) was found to be $800 \mathrm{mg} / \mathrm{kg}$ (i.p.).

\section{Haemolytic activity of the extract}

TTE produced concentration-dependent lysis of washed rat erythrocytes (both direct and indirect). The $\mathrm{HD}_{50}$ dose (amount of extract which causes $50 \%$ lysis of erythrocytes) of the extract was found to be $132 \mu \mathrm{g} / \mathrm{ml}$ (for direct haemolysis model) and $57 \mu \mathrm{g} / \mathrm{ml}$ (for indirect lysis) respectively (Fig. 1). Moreover, TTE was found to be more potent in the indirect haemolytic model of the study (Fig. 1).

\section{Haemorrhagic and necrotizing activities}

Intradermal administration of the TTE $(30 \mu \mathrm{g})$ produced prominent haemorrhagic lesions, measuring 10.75 $\pm 0.73(\mathrm{n}=6) \mathrm{mm}$ in diameter (Fig. 2). However, no significant necrotic lesions could be observed even after $72 \mathrm{~h}$ of observation.

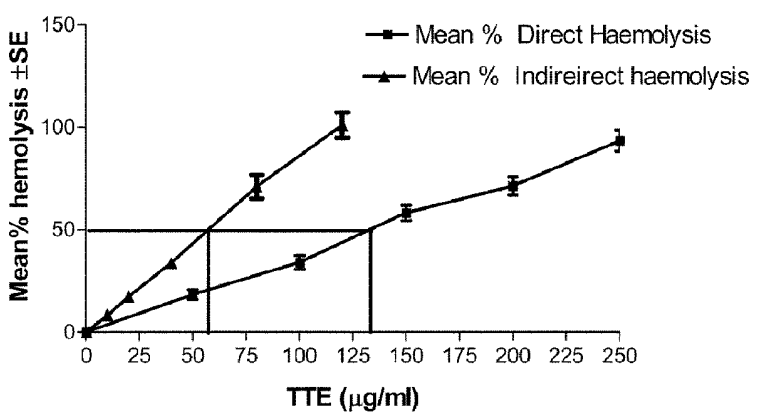

Fig. 1. Evaluation of direct and indirect haemolytic activity of the Telescopium telescopium extract (TTE) on washed rat erythrocytes. Values are represented as mean percentage haemolysis \pm S.E. $(n=6)$.

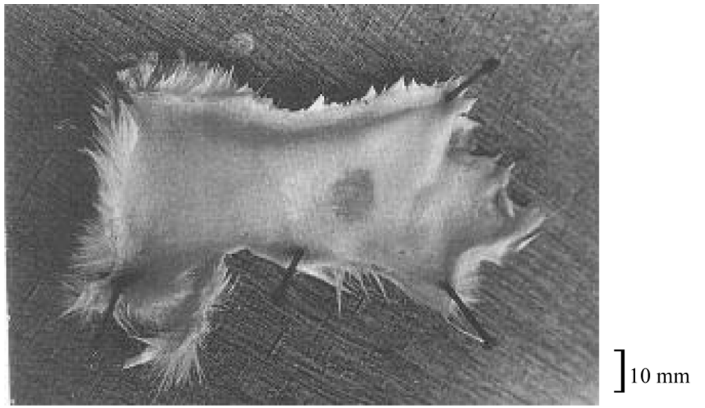

Fig. 2. Haemorrhagic lesions following intradermal administration of the TTE (30 $\mu \mathrm{g})$ observed after $2 \mathrm{~h}$.

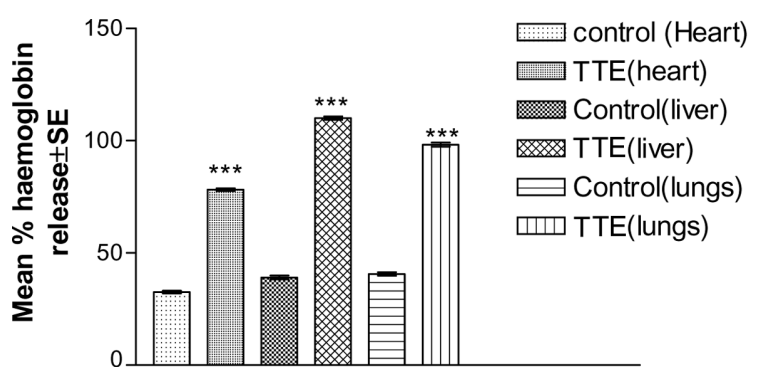

Fig. 3. Effect of the extract on in vitro tissue damage. Percentage of heamoglobin release by the TTE from chicken heart, lung and liver was measured at 540 $\mathrm{nm}$. Values are mean percentage \pm S.E. $(\mathrm{n}=6),(P$ versus control, by " $t$ " test, $\left.{ }^{* * *}<0.001\right)$.

\section{Pathophysiological effect of TTE (in vitro tissue damage)}

TTE demonstrated significant haemoglobin releasing activity (in vitro tissue damage) on incubation with tissue samples from chicken lung, heart and liver. From the results, it was further evident that TTE produced maximum haemoglobin release from the chicken lungs (Fig. 3).

Effect of toxin on vascular permeability (Dye permeability and Protein exudation)

TTE increased acetic acid induced peritoneal exudation and also peritoneal dye leakage. Moreover, TTE (i.p.) also produced significant increase of vascular permeability even in the absence of acetic acid (Table 1).

\section{Release of Autacoids.}

TTE caused significant and dose-dependent, release 
Table 1. Effect on vascular permeability following TTE induced peritoneal inflammation

\begin{tabular}{lcc}
\hline \multirow{2}{*}{ Test substances } & \multicolumn{2}{c}{ Effect on Vascular Permeability } \\
\cline { 2 - 3 } & $\begin{array}{c}\text { Peritoneal Dye leakage } \\
\text { (Absorbance at 625 nm) }\end{array}$ & $\begin{array}{c}\text { Peritoneal Protein Exudation } \\
(\mathrm{mg} / \mathrm{ml})\end{array}$ \\
\hline N.S. (Control) & $0.036 \pm 0.002$ & $02.367 \pm 0.357$ \\
TTE & $0.165 \pm 0.011^{*}$ & $07.883 \pm 0.323^{*}$ \\
N.S+Acetic acid & $0.305 \pm 0.192^{*}$ & $12.080 \pm 0.538^{*}$ \\
TTE+Acetic acid & $0.494 \pm 0.184^{*}$ & $14.520 \pm 0.633^{*}$ \\
Aspirin+Acetic acid & $0.091 \pm 0.008$ & $06.100 \pm 0.547$ \\
\hline
\end{tabular}

NB: NS (Normal Saline); TTE (Telescopium telescopium).

Values are mean \pm S.E. $(\mathrm{n}=6)$. $\left(P\right.$ versus control, by Post Dunnet's test, $\left.{ }^{*}<0.005\right)$.

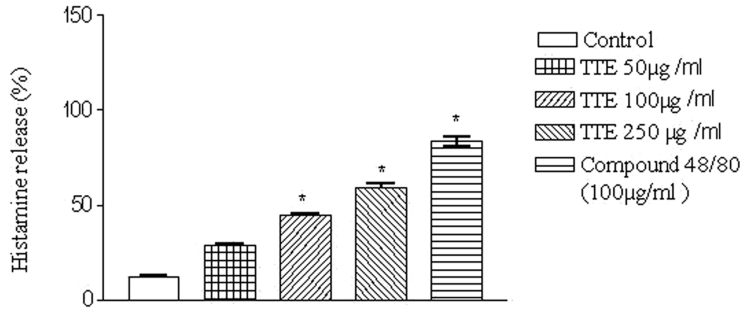

Fig. 4. Effect of TTE on histamine release from peritoneal mast cell. Values are percentage mean of histamine release \pm S.E. $(n=10)$, $(P$ versus control, by Post Dunnet's test * $<0.005)$.

of histamine from peritoneal mast cells. However, incubation of TTE (up to $1000 \mu \mathrm{g} / \mathrm{ml}$ ) with platelets did not produce any significant change in serotonin release (Fig. 4).

\section{Rat Blood Pressure}

Intravenous administration of TTE (0.1 and 0.2 $\mathrm{mg} / \mathrm{kg}$ ) produced a decrease in blood pressure in anaesthetized rat. The normal blood pressure was restored after a period of $10 \mathrm{~min}$ (Fig. 5).

\section{Oedemogenic activity}

Intraplantar administration of TTE produced significant

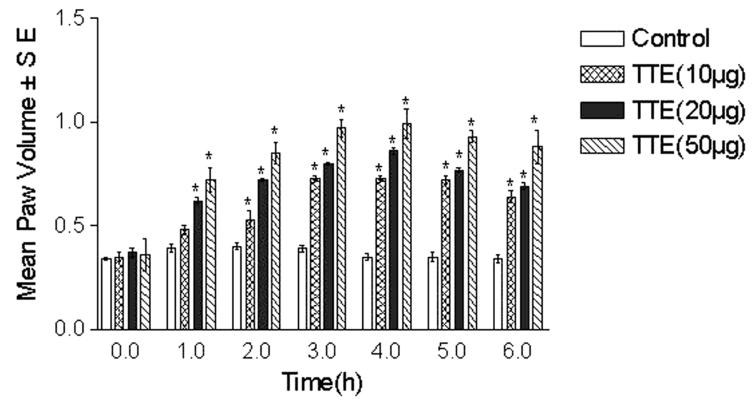

Fig. 6. Oedemogenic activity of TTE on rat paw. Test samples were injected into subplantar region of the left hind paw. Edema was calculated as the difference in paw volumes. Values were mean \pm S.E. $(n=6)$, $(P$ versus control, by Post Dunnet's test $\left.{ }^{*}<0.005\right)$.

and dose-dependent increase of paw volume (oedema formation) up to a period of $4 \mathrm{~h}$ (Fig. 6).

\section{Enzymatic activity of TTE}

Incubation of TTE with different substrates revealed the presence of diverse enzymatic activities. The extract (TTE) demonstrated potent protease, AChE, phospholipase, alkaline phosphatase and esterase activities in the following order: esterase $>$ alkaline phosphatase $>$ phospholipase $>$ acetylcholine esterase

$80 \mathrm{mmof} \mathrm{Hg}$.

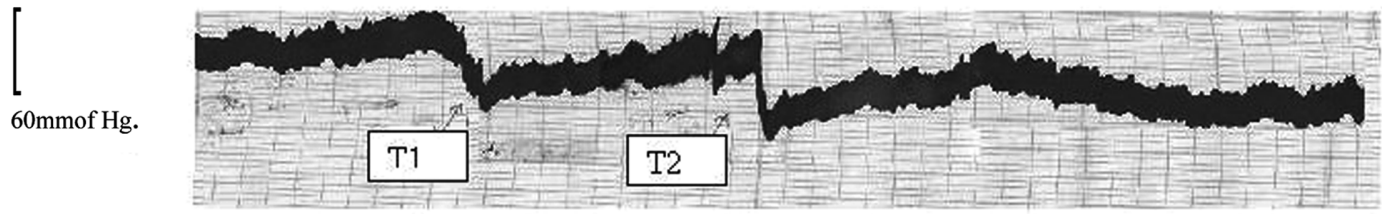

Fig. 5. Effect of TTE on rat blood pressure. Test samples (T1 $=50 \mathrm{mg} / \mathrm{kg}$ and $\mathrm{T} 2=100 \mathrm{mg} / \mathrm{kg})$ were administered through cannula attached with the jugular vein and blood pressure was measured by Grass Polygraph (Model 79). 
Table 2. Enzymatic activity of TTE as observed on incubation of TTE with different substrates (acetylthiocholine iodide, lecithin, fluorescein diacetate, casein and p- nitrophenyl phosphate)

\begin{tabular}{lc}
\hline Enzymatic activity & $\begin{array}{c}\text { Specific activity } \\
\text { (U/mg of protein) }\end{array}$ \\
\hline Acetylcholine Esterase activity & 0.18 \\
Phospholipase $\mathrm{A}_{2}\left(\mathrm{PLA}_{2}\right)$ activity & 0.24 \\
Esterase activity & 0.32 \\
Protease activity & 0.16 \\
Alkaline Phosphatase activity & 0.26 \\
\hline
\end{tabular}

$>$ protease (activity represented in milligrams of protein; Table 2).

\section{DISCUSSION}

The bioactive components of marine mollusks have been reported to contain different types of bioactive components, namely neurotoxin, haemolysin, cardiotoxin, cholinesterase and also various biogenic amines (Narahasi, 1974; Roseghini et al., 1996). Telescopium telescopium, an edible gastropod, is widely found in the Eastern coastline of India. In the present study, the Telescopium telescopium tissue extract was tested for different pharmacological and biochemical activities.

From the results, it was observed that TTE demonstrated both direct and indirect haemolytic effects. The indirect $\left(\mathrm{HD}_{50} 57 \mu \mathrm{g} / \mathrm{ml}\right)$ activity was found to be more potent when compared to the direct haemolytic $\left(\mathrm{HD}_{50} 132 \mu \mathrm{g} / \mathrm{ml}\right)$ effect. Moreover, both indirect haemolysis as well as the oedemogenic property of TTE were effectively inhibited by different phospholipase blockers (data not shown). It is also known that phospholipases present in several animal venoms impart their action on cell membranes via indirect haemolytic action (Gary et al., 2000). However, a majority of $\mathrm{PLA}_{2}$ are also known to be devoid of direct haemolytic activity (Robin Dolley et al., 2003). Therefore, the present findings with TTE indicate the probable involvement of a phospholipase $\mathrm{A}_{2}$ like component.

Furthermore, from our studies it could be observed that TTE exhibited weak proteolytic activity. Since proteases are known to contribute greatly towards excessive protein degradation in intact cell membranes (Santamaria et al., 2002), it can be assumed that the observed proteolytic activity may be a contributing factor during the erythrocyte lysis.

TTE was found to release haemoglobin on incubation with chicken lung tissue in a manner similar to a phospholipases. NK-PLA2 isolated from Indian monocled cobra (Naja kauthia) venom, which has also been found to produce similar effects in chicken heart, liver and lung tissue strips (Robin Doley et al., 2003). Therefore, the tissue damaging activity of TTE could be attributed to the rupturing of blood capillaries, which is necessary for the release of haemoglobin. This rupturing of capillaries may be contributed by $\mathrm{PLA}_{2}$ and the accompanying proteases present in the extract. However, the haemoglobin release was found to be tissue dependent (highest in lungs) The variable activity could be attributed to the tissue specific phospholipids/cholesterol ratio, presence of specific phospholipids and the vitamin E content of the tissue (Kini, 1997; Mukerjee et al., 1998).

Local oedema, redness and pain are some of the major pathophysiological manifestations that have been reported to occur with many different marine species (e.g. jellyfishes, sea anemones), including Telescopium telescopium. In our present study, both TTE $(60 \%$ at a dose of $250 \mu \mathrm{g} / \mathrm{ml})$ and compound $48 / 80(82 \%$ at a dose of $100 \mu \mathrm{g} / \mathrm{ml})$ were found to liberate histamine from the mast cells. Furthermore, intraperitoneal administration of TTE produced extensive peritoneal exudation as evident from increased protein content (of the peritoneal exudates), along with increased dye leakage in the peritoneal cavity, indicating the role of TTE on capillary permeability. These findings were further reinforced by the oedemogenic property, observed with TTE. Furthermore, TTE also produced hypotensive effect in anaesthetized rat, and such activity in turn could be correlated to the increased capillary 
permeability and histamine liberation (Furchgott, 1984).

It was observed that TTE produced severe edema in rat hind paw within $1 \mathrm{~h}$ following subplantar injection and the swelling was found to persist for several hours. The oedemogenic (proinflammatory) activity of the extract was significantly inhibited by various phospholipase inhibitors, indicating the probable involvement of phospholipase (s) enzyme like component (s) in the extract.

The extract also produced strong esterase activity, as was evident from the breakdown of FDA and subsequent release of fluorescin (in vitro). The extract also demonstarted alkaline phosphatase, phospholipase, cholinesterase (a promising biomarker for environmental monitoring and a therapeutic target) and protease activities. The alkaline phosphatases (AP) from marine sources appear to be very interesting for the understanding of life forms at high salinity and are also correlated with inorganic phosphate starvation.

Therefore, on the basis of the present investigations, Telescopium telescopium was found to contain a variety of interesting biological activities and therefore warrants further evaluation.

\section{ACKNOWLEDEGEMENTS}

This investigation was partly supported by a research grant and fellowship (SKS) from CSIR, New Delhi, India. We would also like to thank DST (Government of India), for providing support (FIST programme). This paper is dedicated to our mentor Prof. AK Nag Chaudhuri.

\section{REFERENCES}

Battin TJ. (1997) Assessment of fluorescein diacetate hydrolysis as a measure of total esterase activity in natural stream sediment biofilms. Sci. Totl. Env. 198, 51-60.

Bloom GD, Haegemark O. (1965) A study on morphological changes and histamine release induced by compounds
48/80 in rat peritoneal mast cells. Exp. Cell. Res. 40, 637-639.

Boman HG, Kaletta U. (1957) Chromatography of rattlesnake: A separation of three phosphodiesterases. Biochem. Biophys. Acta. 24, 619-623.

Bradford MM. (1976) A rapid and sensitive method for the quantitation of microgram quantities utilizing the principle of protein dye binding. Anal. Biochem. 72, 248-254.

Cutler RL, Yellowlees D. (1979) Purification and characterization of two endo-(1 linked to 3)-beta-Dglucanases from Telescopium telescopium. Carbohydr. Res. 75, 221-229.

Datta K, Bhattacharya D. (1999) In vitro haemorrhagiclike activity of the Russell viper (Vipera russelli) venom from eastern Indian with mice organs. Curr. Sci. 77, 1673-1677.

Doley R, Mukherjee A. (2003) Purification and characterization of an anticoagulant phospholipase $\mathrm{A}_{2}$ from Indian monocled cobra (Naja kaouthia) venom. Toxicon. 41, 81-91.

Dong G, Zeikus JG. (1997). Purification and characterization of alkaline phosphatase from T. neopolitana. Enz. Microb. Technol. 21, 335-340.

Elizabeth W, Bingham, Kristian G, Doris P. (1992) Purification and Properties of Alkaline Phosphatase in the Lactating Bovine Mammary Gland. J. Dairy Sci. 75, 3394-3401.

Furchgott RF. (1984) The role of endothelium in the responses of vascular smooth muscle to drug. Ann. Rev. Pharmacol. Toxicol. 24, 175-179.

Gary R, Grotendorst, David A. (2000) Enzymatic characterization of the mazor phospholipase A2 component of sea anemone (Aiptasia pallida) nematocyst venom. Toxicon. 38, 931-934.

Gutierrez JM, Gene JA, Rojas G, Cerdas L. (1985) Neutralization of proteolytic and haemorrhagic activity of Costa Rican snake venoms by polyvalent antivenom. Toxicon. 23, 887-893.

Gutierrez JM, Rojas G, Lomonate B, Gene JA, Cerdas L. (1986) Comperative study of the edema-forming activity of Costa Rican snake venoms and its neutralization by a polyvalent antivenom. Comp. Biochem. Physiol. 85, 171-175.

Hamann MT, Otto CS, Scheuer PJ. (1996) Kahalalides: Bioactive peptides from a marine mollusk Elysia rufescens and its algal diet Bryopsis sp. J. Org. Chem. 
61, 6594-6660.

Hamann CB. (1943) Estimation of histamine in the blood and other tissues of rats and guineapig infected with Trichinella Spiralis. J. Parasitol. 29, 367372.

Kini RM. (1997) Phopholipase $\mathrm{A}_{2}$-a complex multicomponent protein puzzle. In: Venom PLA2 enzymes. Structure, Function and Mechanism of action, edited by Kine RM. p.1-28, Willey, New York.

Kondo H, Ikezawa I, Murata R, Ohsaka A. (1960) Studies on the quantitative method for the determination of haemorrhagic activity of Habu snake venom. Jpn. J. Med. Sci. Biol. 13, 43-51.

Litchfield JT, Wilcoxon F. (1949) A simplified method of evaluating dose effects experiments. J. Pharmac. Exp. Ther. 96, 99-102.

Lobo de Araujo A, Radvanyi F. (1987) Determination of phospholipase $\mathrm{A}_{2}$ activity by a colorimetric assay using a $\mathrm{pH}$ indicator. Toxicon. 25, 1181-1188.

McCarthy PJ, Pomponi SA. (2004) A search for new Pharmaceutical Drugs from marine organisms. Marine Biomed. Res. 1, 1-2.

Mukerjee AK, Maity CR. (1998). Composition of Naja naja venom sample from three districts of West Bengal. Eastern India. Comp. Biochem. Physiol. 119, 621-627.

Myers PA, Cruz LZ, Rivier JE, Olivera BM. (1993) Conus peptides a chemical probes for receptors and ion channels. Chem. Rev. 93, 1923-1936.

Pakrashi A, Datta U, Choudhury A. (1992) A search for immunocontraceptive agent from marine sources-role of antispermatheca globulin of Telescopium telescopium on fertility regulation in male rat. Indian J. Exp. Biol. 30, 1066-1074.

Pakrashi A, Roy P, Datta U. (2000) Antimicrobial effect of protein(s) isolated from a marine mollusk Telescopium telescopium. Indian J. Physiol. Pharmacol. 45, 249-252.
Pantazaki AA, Karagiorgas AA, Kyriakidis DA. (1998) Hyperalkaline and therstable alkaline phosphatase in T. thermophilus. Appl. Biochem. Biotechnol. 75, 249-259.

Posen S. (1967) Alkaline phosphatase. Ann. Rev. Intern. Med. 67, 183-203.

Puri VN, Saha S. (2003) Comparision of acute Cardiovascular Effects of Cadmium and Captopril in relation to oxidant and angiotension Converting Enzyme activity in Rats. Drug chem. tox. 26, 213-218.

Rocha-Campos ACM, De Freitas MCW, Yamaguchii IK, Marcelino JR, Dias da Silva W. (1996) A sensitive and specific immunoassay for the measurement of the antibodies present in horse antivenoms endowed with the capacity to block the phospholipase $\mathrm{A}_{2}$ dependent haemolysis induced by snake venoms. J. Venom. Anim. Tox. 2, 106-120.

Rosenfeld G, Kelen EMA, Nudel F. (1962) Haemolytic activity of animal venoms. I. Classifications in different types and activities. Mem. Inst. Butantan. 30, 103-116.

Roy DK, Manisenthil KT, Zothanpuia, Karmakar SK, Pal S, Samanta SK, Adhikari D, Sen T. (2007) Pharmacological studies on Indian Black Tea (leaf variety) in acute and chronic Inflamatory condition. Phytotherapy Res. In press.

Santamaria A, Rodriguez-Sanchez J, Zugasti A, Martinez A, Purelas- Segurea L. (2002). A venom extract from the sea anemone B. annulata produces haemolysis and lipid peroxidation in mouse erythrocytes. Toxicology 173, 221-228.

Theakson RDG, Reid HA. (1983) Development of simple standard assay procedures for the characterization of snake venoms. Bull. Wld. Hlth. Org. 61, 949-956.

Toh CC. (1956). Release of 5-HT (serotonin and histamine) from platelets by tissue extracts. J. Physiol. 33, 402-406. 